\title{
Mitochondrial Activity and Cell Damage after Application of Acmella oleracea Leaf Extract
}

\section{Carlos Augusto Priante da Silva ${ }^{*}$, Cristina Pacheco Soares' ${ }^{1}$, Walderez Moreira Joaquim², Renato Farina Menegon ${ }^{3}$}

${ }^{1}$ Instituto de Pesquisa e Desenvolvimento (IP \& D), Laboratório de Dinâmica de Compartimentos Celulares, Universidade do Vale do Paraíba (Univap), São José dos Campos, Brazil

${ }^{2}$ Instituto de Pesquisa e Desenvolvimento (IP \& D), Laboratório de Fotoacústica Aplicada a Sistemas Biológicos, Universidade do Vale do Paraíba (Univap), São José dos Campos, Brazil

${ }^{3}$ Laboratório de Insumos Naturais e Sintéticos, Universidade Federal de São Paulo (Unifesp), Diadema, Brazil

Email:*cpriante@univap.br, cpsoares@univap.br,wal@univap.br, renato.farina@unifesp.br

How to cite this paper: da Silva, C.A.P., Soares, C.P., Joaquim, W.M. and Menegon, R.F. (2016) Mitochondrial Activity and Cell Damage after Application of Acmella oleracea Leaf Extract. American Journal of Plant Sciences, 7, 2498-2504.

http://dx.doi.org/10.4236/ajps.2016.717217

Received: November 24, 2016

Accepted: December 13, 2016

Published: December 16, 2016

Copyright $\odot 2016$ by authors and Scientific Research Publishing Inc. This work is licensed under the Creative Commons Attribution International License (CC BY 4.0).

http://creativecommons.org/licenses/by/4.0/

\begin{abstract}
Acmella oleracea is a plant species belonging to the Asteraceae family, native to the Amazon that has broad therapeutic and culinary use. Several secondary metabolites and your bioactive component spilanthol have been associated with its medicinal effects. This study aims to evaluate the leaf extract of $A$. oleracea for therapeutic purposes. When applied to both cell cultures HEp-2 neoplastic cells and L929 fibroblast cells, the increasing extract concentrations yielded a significant reduction in cell viability using ANOVA test with Significance of $\mathrm{P} \leq 0.05\left(^{*}\right)$, Very Significant $\mathrm{P} \leq 0.01$ $\left.{ }^{(* *}\right)$ and Extremely Significant $\mathrm{P} \leq 0.001\left(^{* * *}\right)$, causing visible damage to cytoskeleton actin filaments. The cytotoxicity of the $A$. oleracea leaf extract may be associated with other components, including flavonoids. Thus, $A$. oleracea has a great cytotoxic activity on tumoral cells and can be considered for future antitumor therapy. However, because of its toxicity to non-tumoral cells, it is essential to evaluate the efficacy of each extract sub-fraction compound, alerting the population for the traditional use of the plant that can cause damage for the consumer.
\end{abstract}

\section{Keywords}

Acmella oleracea, Jambú, Cytoskeleton, Nuclei, Cytotoxicity

\section{Introduction}

Acmella oleracea ( $L$ ) R.K. Jansen (A. oleracea) is an herbaceous plant from the Asteraceae family native to the Amazon, known as jambú and very popular in Brazil. It is widely used in cooking, especially in Northern Brazil [1]. Alkylamides, such as spilanthol (N- 
isobutylamide), are responsible for its chemical properties [2] [3] [4]. Spilanthol is obtained from the flowers and leaves and has several medicinal uses, as in the treatment of diseases such as stomatitis, anemia, dyspepsia and malaria. Research has also demonstrated its diuretic, antibacterial and anti-inflammatory action [5] [6]. As is the case of any widely used medicinal plant, several preliminary studies are important to determine its properties. This study aimed to evaluate the previous cytotoxicity of the A. oleracea leaf extract using the primary test of cell viability and identify its potential damage to tumoral and non-tumoral cells, determining if the plant has anticancer qualities.

\section{Materials and Methods}

\subsection{Cell Lines}

HEp-2 (human laryngeal carcinoma, ATCC CCL-23) and L929 (mice fibroblasts, ATCC CCL-1) cell lines were obtained from the Cell Culture Section at the Adolfo Lutz Institute (São Paulo, SP). The cells were maintained in MEM (Essential minimal medium, Invitrogen ${ }^{\oplus}$ ) supplemented with $10 \%$ Fetal Bovine Serum (FBS). Before each test, the cells were trypsinized and concentrations of $10^{5}$ cells/well were cultivated in 24-well culture plates and incubated overnight at $37^{\circ} \mathrm{C}$ under $5 \% \mathrm{CO}_{2}$ atmosphere. After incubation, the extract was added to the cell cultures in standard concentrations for cytotoxic tests of $250 \mu \mathrm{g} / \mathrm{mL}, 500 \mu \mathrm{g} / \mathrm{mL}$ and $1 \mathrm{mg} / \mathrm{mL}$ and incubated for another 24 and 48 $\mathrm{h}$ at $37^{\circ} \mathrm{C}$ under $5 \% \mathrm{CO}_{2}$ atmosphere.

\subsection{Extraction Process}

The seeds of the plants used were purchased from a store specializing in seeds and grown in greenhouses at the dependences of the University of Vale do Paraíba. Extraction from A. oleracea leaves was carried out together with the Organic Synthesis Lab of the Research and Development Institute (IP \& D) of UNIVAP, São José dos Campos, SP. A. oleracea leaves collected from the greenhouses were dried in an oven at $45^{\circ} \mathrm{C}$ for 5 days and then ground in a mortar, yielding 17.07 of powder. From this compound, 4 g were transferred to a Soxhlet extraction apparatus MARCONI (MA-044/091-Brazil) using $100 \mathrm{~mL}$ of $70 \%$ ethanol as a solvent running for $1 \mathrm{~h}$ for each $4 \mathrm{~g}$ of extraction material. After extraction, the solvent was evaporated under pressure using a rotary-evaporator at $60^{\circ} \mathrm{C} .100 \mathrm{mg}$ of the obtained residue were dissolved in $1 \mathrm{ml}$ of methanol for subsequent cell application.

\subsection{Cytotoxicity test}

MTT assay (3-bromide (4.5-dimetiltiazol-2-yl)-2.5-difeniltetrazólio) was performed following the protocol previously mentioned in section 2.1. After plating, the cells were incubated in various extract concentrations for 24 and $48 \mathrm{~h}$ at $37^{\circ} \mathrm{C}$ under $5 \% \mathrm{CO}_{2}$ atmosphere. In addition, small pieces of a disposable glove in the wells form the control negative for comparison with capacity cytotoxic of extract, and cell-only groups, with-

out extract, form the positive control. After incubation, the cells were washed with PBS 
(Phosphate Buffered Saline), MTT was added and the plate was incubated for $60 \mathrm{~min}$ at $37^{\circ} \mathrm{C}$. The absorbance of the plated cultures was read in a spectrophotometer (Elisa Spectracount, Packard, USA) in $570 \mathrm{~nm}$. The statistical analysis was performed by the ANOVA test with Significance of $P \leq 0.05\left(^{*}\right)$, Very Significant $\mathrm{P} \leq 0.01\left(^{* * *}\right)$ and Extremely Significant $\mathrm{P} \leq 0.001\left(^{* * * *}\right)$ when compared to the control group + .

\subsection{Fluorescence Labels: Nucleus and Cytoskeleton}

In order to evaluate the integrity and the possible presence of micronuclei in both HEp-2 and L929 cells, they were labeled with DAPI (4',6-Diamidino-2-phenylindole) diluted in PBS in a concentration of $300 \mathrm{nM}$. After incubation, the culture medium was removed from the wells and the cells were washed with PBS before adding $100 \mu \mathrm{L}$ of DAPI and incubating for $5 \mathrm{~min}$. To evaluate cytoskeleton label integrity, both lines cells were labeled with Phalloidin-TRITC. After incubation with the extract, $0.2 \%$ Triton $\mathrm{X}-100$ were applied to the cells in PBS for $10 \mathrm{~min}$ and next incubated for $1 \mathrm{~h}$ with $20 \mu \mathrm{L}$ of Phalloidin-TRITC. Labeled nuclei and cytoskeleton were analyzed in a fluorescence microscope (Leica DMLB) coupled with a Leica MPS-30 photographic system.

\section{Results and Discussion}

After cell incubation with the $A$. oleracea leaf extract, all concentrations were tested in two incubation periods, 24 and $48 \mathrm{~h}$. A considerable decrease in both HEp-2 and L929 cell viability was observed. The extract cytotoxicity was visible after the MTT test, which gave greater probable death index values for the incubation period of $48 \mathrm{~h}$ for both cell lines. The highest reduction of mitochondrial activity with significance was obtained with extract concentration of $1 \mathrm{mg} / \mathrm{mL}$, (Figure 1, Figure 2), with possible cell death in non-tumoral and tumoral lineages. In the L929 cells the reduction in the absorbance values was significance in all concentrations tested in the period of $24 \mathrm{~h}$ and $48 \mathrm{~h}$.

Analysis of the photomicrographs in Figure 3, Figure 4 revealed that the A. oleracea extract induces cytoskeleton disorganization with actin filament disruption. The disorganization occurred in all extract concentrations tested in both incubation periods, with a gradual frequency increase for the tested concentrations. However, the extract concentration had a small effect on cell nuclei, with low frequency of micronuclei.

These results are associated with the plant extract composition. The observed cytotoxicity may be a consequence of metabolite activity and be responsible for its medicinal properties. The toxic activity of flavonoids in tumoral cells has been described in several studies, which have also indicated that compounds with 3-methoxy inhibit tubulin polymerization and induce cell death by apoptosis as well by stimulating the release of cytochrome c. [7] Studies indicate the presence of these substances in A. oleracea, but not of cytotoxic derivatives in these compounds [8] [9].

\section{Conclusions}

The reduction in cell population observed in the MTT test indicates that the $A$. oleracea 


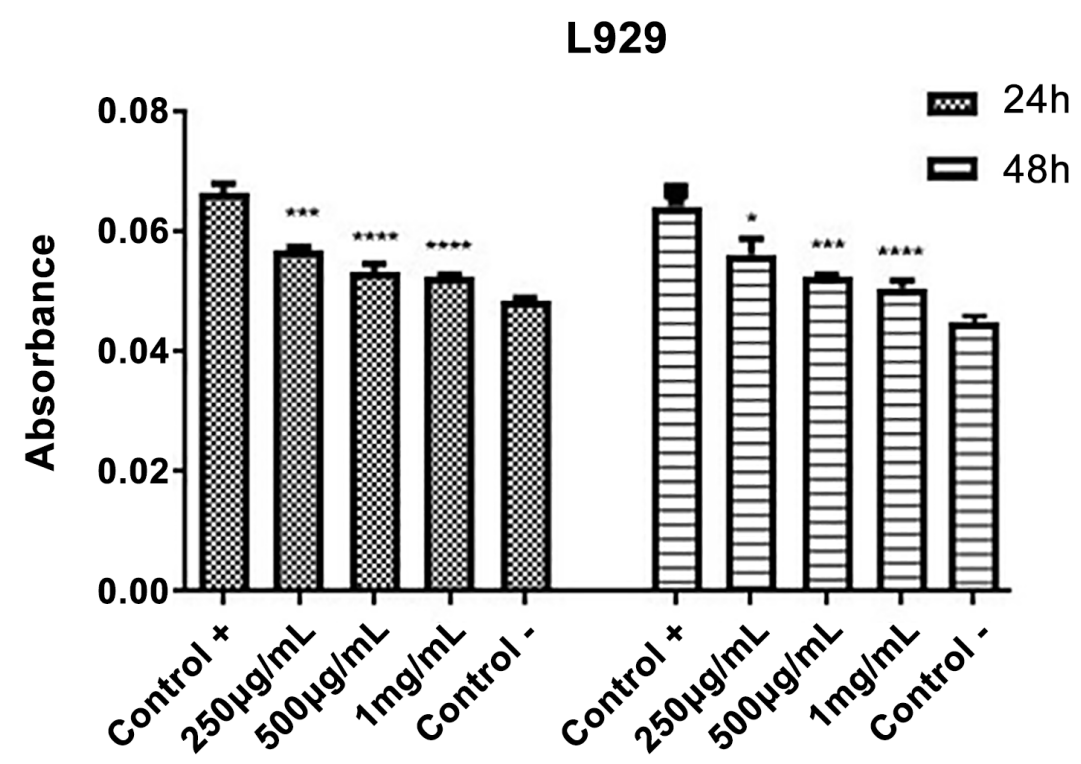

Figure 1. MTT plot of L929 cells incubated for 24 and $48 \mathrm{~h}$ in A. oleracea leaf extract. The highest absorbance reduction was observed at a concentration of $1 \mathrm{mg} / \mathrm{mL}$. The concentrations of $500 \mu \mathrm{g} / \mathrm{mL}$ and $250 \mu \mathrm{g} / \mathrm{mL}$ yielded growth inhibition with significance in both periods. The smallest cell reduction index was observed for an extract concentration of $250 \mu \mathrm{g} / \mathrm{mL}$ in $48 \mathrm{~h}$ by the ANOVA test with Significance of $\mathrm{P} \leq 0.05$ $\left.{ }^{*}\right)$, Very Significant $\mathrm{P} \leq 0.01\left(^{* * *}\right)$ and Extremely Significant $\mathrm{P} \leq 0.001\left(^{* * *}\right)$ when compared to the control group + .

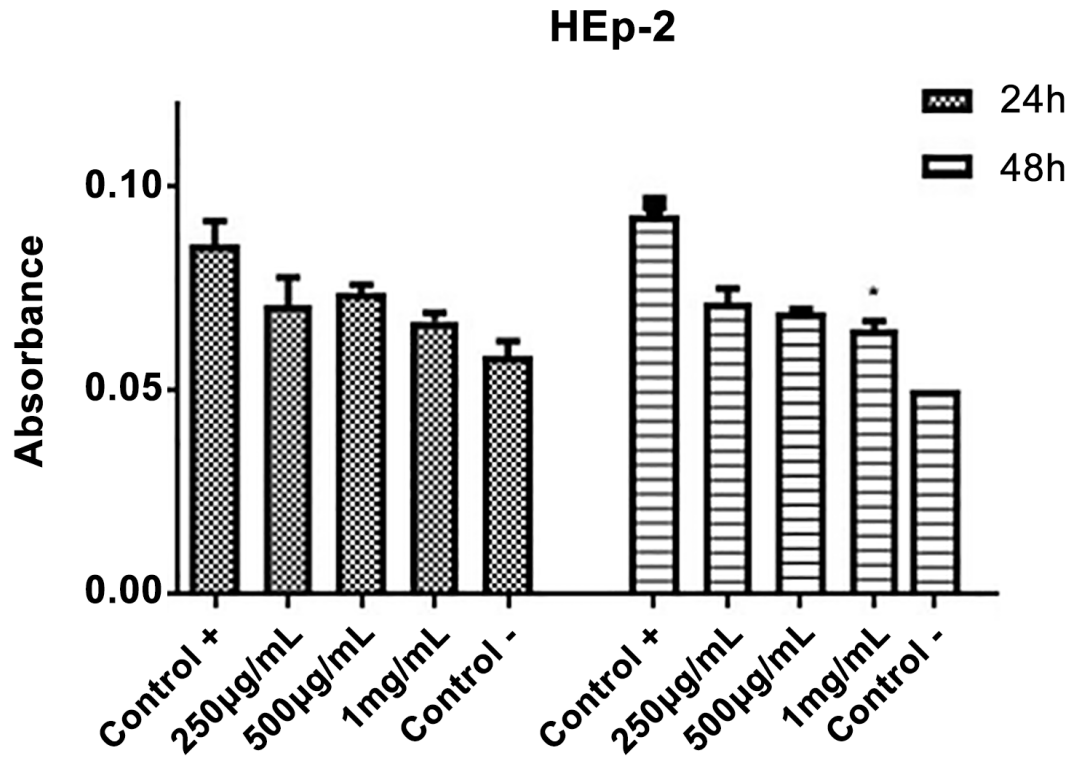

Figure 2. MTT test graph of L929 cells incubated for 24 and $48 \mathrm{~h}$ in A. oleracea leaf extract. The highest absorbance reduction was observed at the concentration of 1 $\mathrm{mg} / \mathrm{mL}$, with significance only in $48 \mathrm{~h}$. The concentrations of $500 \mu \mathrm{g} / \mathrm{mL}$ and 250 $\mu \mathrm{g} / \mathrm{mL}$ yielded growth inhibition indexes but without significance by the ANOVA test with Significance of $\mathrm{P} \leq 0.05\left(^{*}\right)$, Very Significant $\mathrm{P} \leq 0.01^{(* *}$ ) and Extremely Significant $\left.\mathrm{P} \leq 0.001{ }^{(* * *}\right)$ when compared to the control group + . 




Figure 3. L929 cells with cytoskeleton labeled with Phalloidin-TRITC in red and nuclei marked with DAPI in blue. Incubation times of $24 \mathrm{~h}$ (left) and $48 \mathrm{~h}$ (right). B, C, D-extract concentrations of $250 \mu \mathrm{g} / \mathrm{mL}, 500 \mu \mathrm{g} / \mathrm{mL}$ and $1 \mathrm{mg} / \mathrm{mL}$, respectively. Negative control group without extract addition. Arrows indicate the presence of disorganization cytoskeleton and arrow head indicates fragmented nuclei. Scale $10 \mu \mathrm{m}$.

leaf extract has antitumoral activity; however, the use of this compound as a cancer therapeutic is not fully viable, since damage to non-neoplastic cells has also been observed.

The action of the extract on the cytoskeleton of both studied cell lines was characterized by actin filament disorganization. The interference in the cell viability in this critical structure indicates the cytotoxic capacity of the plant extract, although the extract 


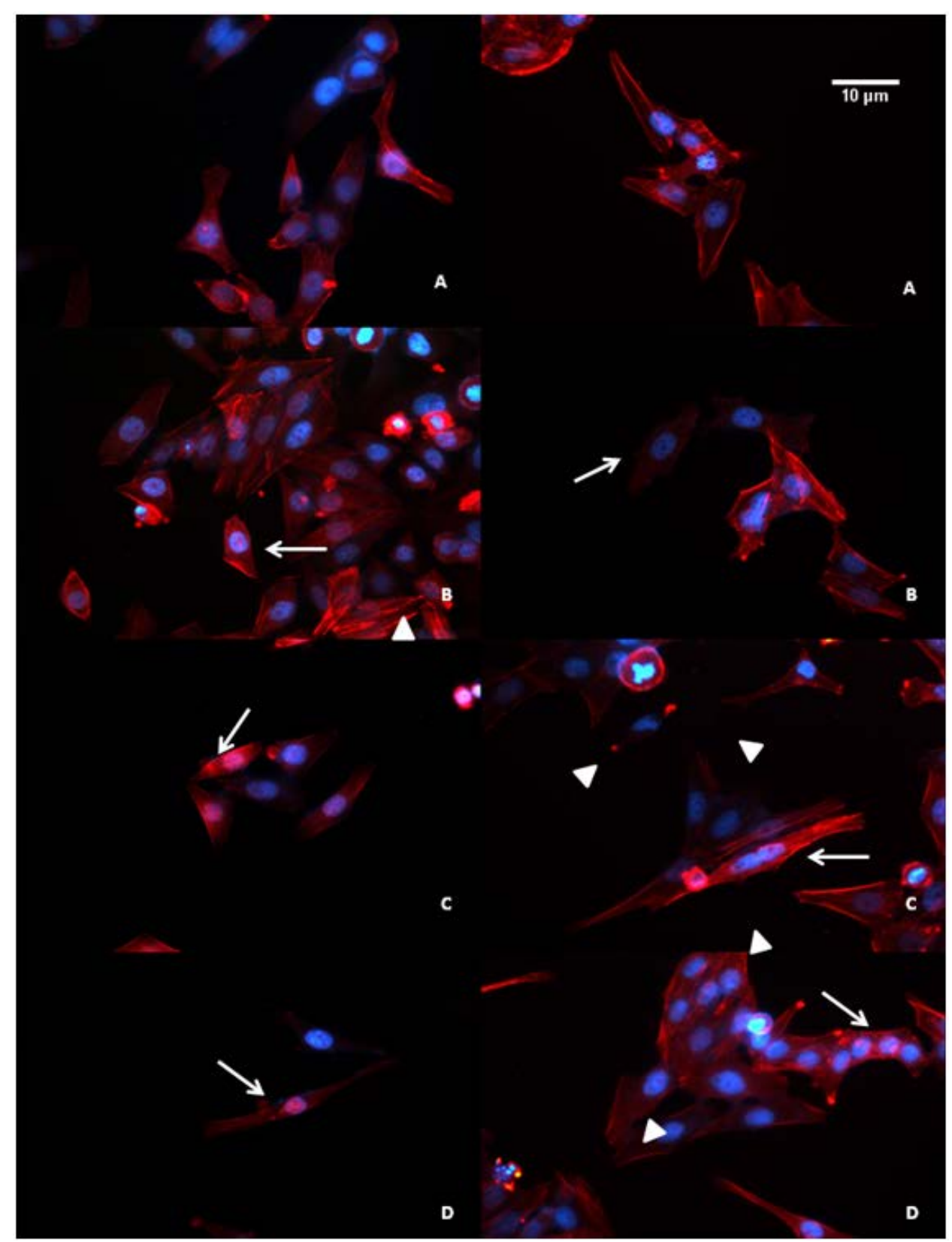

Figure 4. HEp-2 cells with cytoskeleton marked with Phalloidin-TRITC in red and core marked with DAPI in blue. Incubation times of $24 \mathrm{~h}$ (left) and $48 \mathrm{~h}$ (right). B, C, D-extract concentrations of $250 \mu \mathrm{g} / \mathrm{mL}, 500 \mu \mathrm{g} / \mathrm{mL}$ and $1 \mathrm{mg} / \mathrm{mL}$, respectively. Negative control group without extract addition. The arrows indicate the presence of disorganization cytoskeleton and the arrow head condensed nuclei or micronuclei and likely cell death. Scale $10 \mu \mathrm{m}$.

doesn't act in the nuclei. These primary, observed damages alert the population for the traditional use of the plant that can cause damage for the consumer.

\section{Acknowledgements}

The authors would like to thank the Undergraduate Research Program and the Organic 
Synthesis Laboratory of Universidade do Vale do Paraíba (UNIVAP) for assistance with plant extraction. This work was supported by Conselho Nacional de Desenvolvimento Científico e Tecnológico (Cnpq) and Fundação de Amparo à Pesquisa do Estado de São Paulo (FAPESP-2009/15206-8).

\section{References}

[1] Pimentel, A.A.M.P. (1985) Olericultura no trópico úmido: hortaliças na Amazônia. Agronômica Ceres, São Paulo.

[2] Villachica, H., Carvalho, J.E.U., Müller, C.H., Diaz, S.C. and Almanza, M. (1996) Frutales y hortalizas promisorios de la Amazônia. Tratado de Cooperacion Amazônica. Secretaria-Pro-tempore, Lima.

[3] Bae, S.S., Ehrmann, B.M., Ettefagh, K.A. and Cech, N.B. (2010) A Validated Liquid Chromatography-Electrospray Lionization-Mass Spectrometry Method for Quantification of Spilanthol in Spilanthes acmella (L.) Murr. Phytochemical Analysis, 21, 438-443. https://doi.org/10.1002/pca.1215

[4] Boonen, J., Baert, B., Burvenich, C., Blondeel, P., de Saege, S. and de Spiegeleer, B. (2010) LC-MS Profiling of N-Alkylamides in Spilanthes acmella Extract and the Transmucosal Behaviour of Its Main Bio-Active Spilanthol. Journal of Pharmaceutical and Biomedical Analysis, 53, 243-249. https://doi.org/10.1016/j.jpba.2010.02.010

[5] Coutinho, L.N., Aparecido, C.C. and Figueiredo, M.B. (2006) Galhas e deformações em jambu (Spilanthes oleracea) causadas por Tecaphora spilanthes (Ustilaginales). Summa Phytopathologica, 32, 283-285. https://doi.org/10.1590/S0100-54052006000300013

[6] Wu, L., Fan, N., Lin, M., Chu, L., Huang, S., Hu, C. and Han, S. (2008) Anti-Inflammatory Effect so Spilanthol from Spilanthes acmella on Murine Macrophage by Down-Regulation LPS-Induced Inflammatory Mediators. Journal of Agricultural and Food Chemistry, 53, 2341-2349. https://doi.org/10.1021/jf073057e

[7] Sonoda, M., Nishiyama, T., Matsukawa, Y. and Moriyasu, M. (2004) Cytotoxic Activities from Two Scutellaria Plants in Chinese Medicine. Journal of Ethnopharmacology, 91, 6568. https://doi.org/10.1016/j.jep.2003.11.014

[8] Lorenzi, H. and Matos, F.J.A. (2002) Plantas medicinais no Brasil: nativas e exóticas. Instituto Plantarum, São Paulo.

[9] Chakraborty, A., Devi, R.K.B., Sanjebam, R., Khumbong, S. and Thokchom, I.S. (2010) Preliminary Studies on Local Anesthetic and Antipyretic Activities of Spilanthes acmella Murr. in Experimental Animals Models. Indian Journal of Pharmacology, 42, 277-279. https://doi.org/10.4103/0253-7613.70106

\section{Abbreviations}

DAPI: 4'-Diamino-6 2-phenyl-indole; MEM: Minimum Essential Medium; MTT: 3bromide (4.5-dimethylthiazol-2-yl)-2.5-diphenyltetrazolium; PBS: Phosphate Buffered Saline; FBS: Fetal Bovine Serum. 
Submit or recommend next manuscript to SCIRP and we will provide best service for you:

Accepting pre-submission inquiries through Email, Facebook, LinkedIn, Twitter, etc. A wide selection of journals (inclusive of 9 subjects, more than 200 journals)

Providing 24-hour high-quality service

User-friendly online submission system

Fair and swift peer-review system

Efficient typesetting and proofreading procedure

Display of the result of downloads and visits, as well as the number of cited articles

Maximum dissemination of your research work

Submit your manuscript at: http://papersubmission.scirp.org/

Or contact ajps@scirp.org 